\title{
4
}

\section{BETWEEN THE MARKET AND CLIMATE CHANGE}

\section{Uncertainty and transformation in Kutch}

Shilpi Srivastava, Lyla Mehta, Lars Otto Naess, Mihir R. Bhatt and V. Vijay Kumar

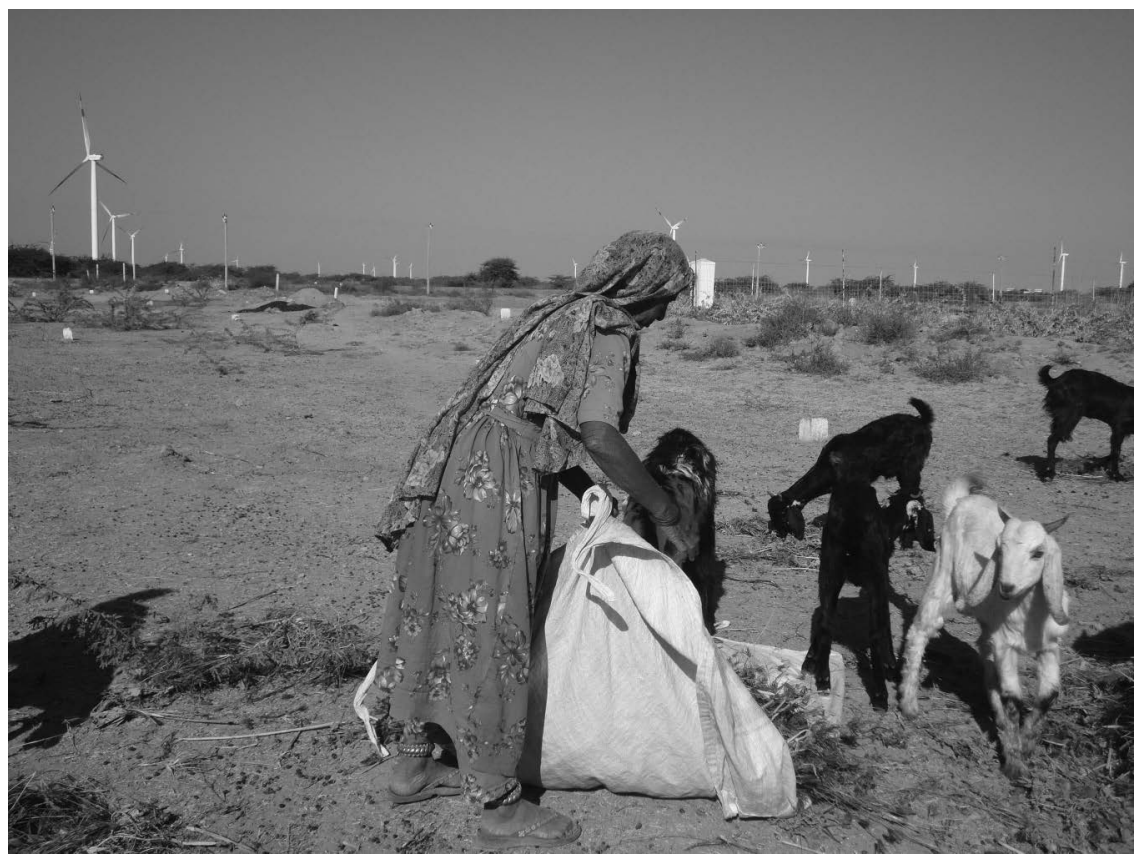

FIGURE 4.1 Coastal infrastructure projects undermine pastoralism in Kutch (Photo credit: Shilpi Srivastava).

\section{Introduction}

“Kudrat ek karishma hai, uske apne tareekein hain, Malik dekh lega!" (Nature is miraculous, it has its ways. God will keep us) - said Omar bhai, former fisher 
now Sufi mystic, when we met him in a small fisher hamlet in Kutch in August 2016. He was referring to the changes in seasonal cycles and attributed these to the miracles and also at times to the wrath of nature. But beneath his sense of poise and calm was an anxiety about the future, about his family, village and their livelihoods. "We have to get by", he said and smiled. This anxiety about the "unknown" is often laced with a staunch belief in divination, be it God or karma, as life and livelihoods become increasingly precarious for these marginal communities in Kutch. This district in Gujarat, western India, has witnessed massive ecological, economic, demographic and social changes in the 21st century. These include aggressive industrialisation and a boom in business activities which have not only led to economic growth for some but also dispossessed many local people from their traditional lands and livelihoods (see below; also see Figure 4.1).

For most rural communities in Kutch, living with uncertainty has been an intrinsic part of their daily lives. For example, droughts have been a part of the ecological rhythm in Kutch and something people living there have been used to dealing with (see Mehta 2005). However, many now say they are struggling to cope due to a combination of, on the one hand, changing rainfall patterns and intensities of droughts and, on the other hand, the compromised ability to tackle these extremes due to wider social and economic changes which have increased precarity and vulnerability.

Once considered to be the backyard of the developed and prosperous state of Gujarat and a "punishment post for bureaucrats" (Mehta 2005: 314), Kutch, especially after the 2001 earthquake, has been slowly and strategically turned into a corporate enclave (Srivastava and Mehta 2017). This new landscape has also made way for a new set of actors. These include big corporate houses that are increasingly laying claims to coastal and marine resources and a vibrant network of civil society organisations (CSOs) working in diverse areas of reconstruction, rights and development (Kohli and Menon 2016).

Thus, this landscape, hitherto considered "remote" and "backward" with respect to mainstream development in India, is now servicing the engines of the capitalist economy through various interventions such as the Special Economic Zones $(\mathrm{SEZs})^{1}$ and renewable energy parks that are making these marginal areas legible to the state and corporate actors (see Damodaran et al., Chapter 3; Scott 1998). In parallel, climate change is also posing a threat to the traditional livelihoods in the district (Mehta et al. 2019). Due to rapid groundwater depletion and poor rainfall, saltwater intrusion has emerged as a major challenge (GUIDE 2014). Furthermore, industrial development in some eco-sensitive zones has affected local livelihoods such as dryland agriculture, fishing and pastoralism (Kohli and Menon 2016).

In this chapter, we investigate how uncertainty is characterised by these diverse actors in Kutch. As discussed in Chapter 1, we use the Kutch case to argue that the increase of extreme events, together with the many ecological, economic and political changes taking place in this remote district, has given 
rise to a more radical form of uncertainty. By radical uncertainty, we mean a situation where the past is no longer a good guide to what the future might hold (Kay and King 2020). This, we argue, creates situations that are not only pushing people to the limits of coping but also reducing their adaptive capacity to live with current as well as future climatic uncertainties. Thus, new ways of anticipating and reimagining these landscapes may be required for socially just transformation in the context of climate change.

After laying out the conceptual framework and methodology, we discuss the varying perceptions of uncertainty from the "above" and "below". This is followed by a short discussion on the role of intermediaries (the "middle") who are instrumental in entrenching or reframing the development narratives, thus becoming the potential facilitators of transformative change in Kutch. We discuss one such example at the end of the chapter.

\section{Radical uncertainty and transformation}

Changing rainfall patterns caused by climate change can increase the severity and frequency of both droughts and floods (Lehmann et al. 2018). This is a cause for concern when these historically new patterns occur in drought-prone areas. While local people may be attuned to coping with climate variability in Kutch, the rapid rise of extreme weather events and high climatic variability has constrained their traditional responses, especially when wider forces in the political economy also limit their adaptive capacity and pathways to address climate-induced uncertainties (Tschakert 2007; Solecki et al. 2017). This intersection of epistemic uncertainty with wider drivers of change leads to what we have called radical uncertainty in this chapter.

In this chapter, we draw on Walker et al.'s (2003) distinction between ontological (uncertainty due to inherent variability of the system) and epistemological uncertainty (uncertainty due to imperfect knowledge) and argue that perceptions of and responses to uncertainty are shaped by diverse factors. These range from dynamic and variable ecological systems (rainfall, temperature, salinity intrusion) to the incumbent knowledge systems and systemic drivers of change (such as industrialisation, water and land grabs) which lead to situated perspectives on uncertainty and also shape particular responses (Haraway 1988; Mehta et al. 2019).

This intersection between these different drivers has material effects and is at the heart of radical uncertainty, which either pushes local people to the limits of coping or compels them to adopt maladaptive pathways that compromise their or others' well-being in different ways (Gajjar et al. 2018; Mehta et al. 2019). It creates what Ribot (2014: 673) has referred to as the "pre-existing precarity that climate change finds in place", which then (re)produces vulnerabilities and may limit future adaptation pathways and choices. For example, we show how the denigration of pastoralism has led several herders to take up precarious and insecure employment and also compromised on their identity and sense of wellbeing (Mehta and Srivastava 2019). 


\section{Uncertainty and transformation}

As argued in the introduction, uncertainties can often create feelings of anxiety and precarity, these should not always be viewed negatively. They may present opportunities, policy windows and spaces that trigger change, disrupt incumbent systems that lock in social inequalities and provide an opportunity to address root causes and in effect "to reconfigure the meaning and trajectory of development" (Pelling 2011: 231). These are broadly characterised as transformations in this chapter.

For example, in the context of climate adaptation, Pelling (2011: 88) notes that "the most profound act of transformation facing humanity as it comes to live with climate change requires a cultural shift from seeing adaptation as managing the environment "out there" to learning how to reorganise social and socioecological relationships, procedures and underlying values "in here"”. In this chapter, we look at transformation as a contested process that may be triggered by various uncertainties but is directed towards social justice, ensuring recognition of livelihood rights of the marginal communities and is attuned to production processes and ecological realities that attempt to re-orient value systems towards social and economic justice. Transformations require moving away from topdown and techno-centric approaches to more plural, place-based and diversified ways of embracing and living with uncertainty which are sensitive to humanenvironment relationships and target the root causes of vulnerability (Eriksen et al. 2015). We argue that such deliberately created spaces can offer possibilities to reimagine radical socio-economic change, which also incorporates ecological considerations (health and quality of the ecosystem) as discussed through the pastoral initiative in this chapter.

\section{Methodology}

This chapter draws on a multi-sited qualitative study, which brings in a long durée perspective going back many decades by two of the authors. Following a literature review on climate change, environmental politics and development in Kutch, fieldwork has been taking place since 2015. To capture the diverse ecosystem and livelihoods profile of Kutch, the ethnographic fieldwork focused on two geographical sites: Merka in Rapar taluka (sub-district) and the coastal village of Jalva and adjoining hamlets in Abdasa taluka. This was complemented by extended field observations in these sites and by an additional short research study undertaken in Tasu and Phuleri vands (hamlets) in Mundra. These sites represent the diverse ecosystems of Kutch (coastal-marine, wetland and dryland) and the predominant livelihoods of the region which are fishing, agriculture and pastoralism. Our field visits aimed to capture uncertainty in different seasons (winters, summers and post-monsoon). Over 70 semi-structured interviews were conducted with herders, farmers and fishers. This local-level fieldwork was complemented by stakeholder interviews, which were conducted in Naliya 
(Abdasa), Bhuj, Gandhinagar and Ahmedabad. Geographically, the "above" and "middle" are spread across the taluka headquarters (Rapar and Naliya), the district headquarter (Bhuj) and the twin cities of Gandhinagar and Ahmedabad. In total, 100 interviews were conducted across the various field sites in Gujarat. ${ }^{2}$

\section{Site description}

Kutch, derived from the Gujarati word Kachua (tortoise), was formed out of the former native State of Kutch and ten enclave villages of the former native State of Morvi (Mehta 2005). Kutch is the largest district in the country covering an area of $45,674 \mathrm{sq} \mathrm{km}$, of which $51 \%$ is covered by the Rann (salt desert) and $15.67 \%$ by forests (Government of Gujarat 2020). It has nine ecological zones that range from the Ranns to the lush green irrigated fields and the Banni. The main occupations are pastoralism, agriculture and fishing, but these are in transition due to changes in the local economy after the 2001 earthquake (discussed "below").

Off the Bhuj-Ahmedabad Highway and bordering the Little Rann of Kutch is the compact village of Merka in Rapar taluka. Merka is a medium-sized village with over 1,000 households that are multi-religious and multi-caste. Caste, wealth, gender, ownership of land and water resources form the important axes of social differentiation (Mehta 2005). Prominent social groups include the erstwhile feudal lords (the Darbars or the Jadeja Rajputs), the Rjputs (also from the so-called warrior castes, but traditionally considered "lower Jadejas" because they gave up certain restrictive feudal and gender practices (cf. Mehta 2005)), the herders (Rabaris and Bharwads) and Dalits (referred to as Harijans in the village), Kolis and Muslims. The Darbars and the Rjputs occupy the village centre and the Harijan, Koli and Muslim vas (settlements) are on the margins. Kolis live in the vand on the periphery of the village. They are one of the least developed communities in Merka with little access to health, water, sanitation and other basic amenities.

The village has a semi-arid climate, and the average annual rainfall is about 365 $\mathrm{mm}$ (Samerth Trust 2013). The prominent livelihood activities are agriculture (which is largely rain-fed), livestock rearing and charcoal making. Like other villages in the district, water is the backbone of the rural economy in Merka. Previously, the villagers depended on open wells and community ponds (gaon talabs) for drinking and livelihood activities, but most of these water sources are either depleted or have fallen into disuse in the last 15 years. With the expansion of settled agriculture, and depletion of other water sources such as ponds, wells and dug wells, groundwater resources are severely strained. Although the village falls within the catchment of the Sardar Sarovar project, which is considered a "lifeline" for Gujarat (see Mehta 2005), water has not yet reached this village and "people are still waiting" (Interviews, January 2016, Merka). For drinking water, people usually rely on the piped water supply but fall back on the wells, especially during the summer months, when the supply is irregular since water is only available once in three days. 
Towards the north-west frontier of the district is Jalva, a large coastal village located in Abdasa taluka, with a population of 5,369 people (Government of India 2011). Since medieval times, the Jalva port has assumed central importance owing to trade links with west Asian and African countries (Ibrahim 2009). Being the last port on the western frontier of India, Jalva has significant strategic importance and the activities are continuously monitored by the Border Security Force (BSF). The village is predominantly Muslim, with the majority of the population belonging to the Vagher community. Other social groups include the Jains or the Vania, Bhanushalis, Lohana, Darbars and Kolis. Given its proximity to the coast, fishing is one of the major livelihoods in Jalva largely practised by the Vaghers and the Kolis. Livestock rearing is also an important livelihood in the village. The maldharis (one who owns and rears livestock) usually live in the simara (the boundary of the village) or small hamlets adjacent to the main Jalva village. One such hamlet is Jimlivand, which is the site for our focused study on Jalva.

Jimlivand, a hamlet of approximately 35 families, is a compact community of Fakirani Jats (different from the Jats of Northern India), a sect influenced by the Sufi tradition, who have settled in various hamlets across the Gujarat coast (Soneji 2017). They claim their ancestral links to the Halaf region in Iran (Bharwada and Mahajan 2007). Although fishing is one of the predominant livelihoods in the community, Jimlivand's identity is closely linked to camel and cattle-rearing, that is, being maldharis. However, the residents have given up on camel breeding and rearing and now keep buffaloes instead. The village now has about 600-700 buffaloes (Srivastava and Mehta 2017).

The average rainfall of the taluka is $371.67 \mathrm{~mm}$ and there has been a slight increase in the rainfall (by 17\%) from 1932 to 2010 (Gujarat Ecology Commission 2011). Declining water quality is a serious issue in Jalva. Most wells in Jalva have now turned saline and are unfit for drinking or irrigation purposes. Piped water supply is irregular and unreliable. With very few freshwater wells, women and young girls have to make several trips to the wells and wait for hours to collect water.

About $150 \mathrm{~km}$ away from Jimlivand is Mundra, a coastal town, which survived the destruction from the 1998 cyclone due to its "thick" mangrove shield (Srivastava and Mehta 2017). A sprawling SEZ has now replaced the mangrove shield. Due to the construction of the SEZ (including the private port), it is estimated that about 3,000 hectares of mangroves were cleared by the Adani Group, and in some cases, as in Mundra and Hazira, they virtually disappeared overnight (Singh quoted in Asher 2008). On the margins of the SEZ are the small-scale fishers (pagadias and boat fishers) and the Rabari camel herders whose livelihoods are at risk due to this large-scale industrialisation (Kachchh Camel Breeders Association 2013).

\section{Kutch: a landscape in transition}

Kutch is socially diverse and is home to several hundred ethnic groups with distinct customs, languages and identities (Mehta 2005). For much of its recorded 
history, emigration has been a way of life in Kutch and its geographical location on the western seaboard provided the required fillip to trade and mercantile activities, which, in part, led to the development of a multicultural and syncretic culture in this region (see also Chapter 3). Ibrahim (2007) locates the development in Kutch along two key axes: one, primarily emerging through the outward-looking trade and migration routes with other seafaring communities in East Africa, Bombay or the Persian Gulf, which she calls the Vaniya-vegetarianpatidar belt, and the other, hitherto neglected but equally important for the rise and sustenance of syncretism in Kutch, are the pastoral communities who were crucial to the overland trade routes through Pakistan, Afghanistan and Central Asia. Before the partition (1947), the Kutchis usually connected with Sindh more than Gujarat, which was often referred to as pardes (foreign land) in oral narratives (Ibrahim 2009; Interview, September 2016, Ahmedabad). Maldharis would often migrate to Sindh in times of drought. The land border after the partition severed these ties and successive India-Pakistan wars sealed the divide.

While irrigated agriculture and maritime development received significant attention after Independence in 1947, the contribution of the pastoral economy to Kutch and her people was both neglected and marginalised (Mehta and Srivastava 2019). State policies and programmes have systematically ignored the particular dynamics around variability, uncertainty and water scarcity in Kutch and the experiences and abilities of local communities, especially pastoralists, to deal with these, thus displaying "dryland blindness" (Mehta 2005). This "dryland blindness" and also the systematic denigration of pastoralism in policy discourses have accelerated with the rapid industrialisation processes that intensified after the 2001 earthquake.

Following the earthquake, Kutch became the symbol of reconstruction and development, a "new resource frontier" whereby the economy, nature and society were re-configured to create "spaces of capitalist transition" (Barney 2009: 146). Tax holidays, port development and the establishment of the SEZ have systematically altered the countryside and the coast leading to substantial changes in the demography, resource ownership and allocation in the region. In the name of development, the economy and social sector were opened to diverse actors, such as NGOs, business and corporate houses and other foundations (Kohli and Menon 2016). We now move on to show how uncertainty and transformation have played out in this altered landscape of Kutch.

\section{Politics and perspective from "above", "middle" and "below"}

Described in some government reports as a "museum of environmental hardship" (cited in Mehta 2005: 11), Kutch's geology, climate and topography make its resource endowments, especially water, crucial to the sustenance of life and livelihoods. The water endowments of the region vary considerably from place to place. They range from areas abundant in groundwater supplies (such as Mandvi) to vast desert-like saline tracts around the Rann. Different social actors 
in Kutch also have highly differentiated access to and control over water and land resources (Mehta 2005).

As a state falling in arid and semi-arid zones, Gujarat has traditionally had a drought cycle of five years, including two years of moderate rainfall, two years of low rainfall and one year of good rainfall (GUIDE 2014). Two or three consecutive years of low rainfall make it difficult for the local communities to sustain their livelihoods. In the period between 1958 and 2007, Kutch recorded the highest annual rainfall variability (57\%) among the districts of Gujarat. Kutch, along with parts of Banaskantha, Patan, Surendranagar, Rajkot and Jamnagar districts, was also found prone to experience moderate to severe droughts in more than 30\% of the years (Pandey et al. 1999, 2009). A 2014 study by the Gujarat Institute of Desert Ecology (GUIDE) also recorded an increase in the number of villages experiencing drought in Kutch over the past two decades (GUIDE 2014).

A long coastline also exposes the state to stressors such as cyclones, sea-level rise and salinity ingress. According to a coastal vulnerability assessment (2015), the Gulf of Khambat and north-western part of the Gulf of Kutch are classified under very high-risk category (Mahapatra et al. 2015). With the warming of the Arabian Sea, cyclonic activities are also likely to be amplified in this region given the recent trends in the incidence of extreme weather events in the Indian Ocean (Sarkar 2020).

Until a few decades ago, droughts and, to a lesser extent, cyclones were the major environmental challenges in the state as well as the district of Kutch. However, in recent times, increasing extreme events such as intense rainfall and heatwaves are adding to environmental vulnerabilities of the district. For instance, in August 2020, various parts of the district were flooded and the region recorded 32\% higher rainfall than the season's average (The Hindu Business Line 2020). Like several other regions, Kutch also has a varied agro-climatic profile with different micro-climates in different regions, which require targeted adaptation strategies. So, how do policymakers and scientists understand climate-related uncertainties in Gujarat and more specifically in Kutch?

\section{The bird's eye view: uncertainty from "above"}

For the "above" in Gujarat, very few actors spoke of climate adaptation and mitigation strategies tailored for one specific region or district in the state. Instead, they largely referred to the aggregate state-level scenario where Kutch featured as one among the many districts of Gujarat which is vulnerable to climate change. This bird's eye view also meant that local perceptions and experiences of climate change rarely featured in policymaking on climate change.

For scientists in Gujarat, climate change is real and certain and is measured through key variables such as temperature, rainfall, sea-level rise and concentration of GHGs in the atmosphere. They concur that what is uncertain is the impact of climate change at the local and regional levels due to limitations of 
downscaling in the Global Circulation Models (GCMs) (Interviews, September 2016 and January 2018, Gandhinagar and Ahmedabad; Sarkar et al. (2015); see also Chapter 2). However, their position and emphasis on each of these variables varied where some tend to focus more on rainfall and adaptation, while others on temperature and atmospheric changes.

Almost all climate scientists that we interviewed agreed that climate change will have unprecedented effects on the social and economic life in Gujarat. Referring to these issues, the Director of IMD (Ahmedabad) stated: "there may be uncertainty about rainfall, but there is no uncertainty about maximum and minimum temperature in Gujarat as heatwaves will become more frequent and oppressive" (Interview January 2018, Ahmedabad).

Specifically for Kutch, a 2015 study on downscaling temperature and rainfall scenarios projects that Kutch is likely to get hotter and wetter by the end of this century. For instance, the study indicates that the daily maximum and minimum temperature would increase by at least $0.4{ }^{\circ} \mathrm{C}, 1.5^{\circ} \mathrm{C}$ and $3.0^{\circ} \mathrm{C}$ during 2011-2030, 2046-2065 and 2080-2099, respectively, compared to the baseline temperature (Sarkar et al. 2015). The study also concluded that rainfall projections were ridden with uncertainties and required further investigation.

For IMD rainfall had a higher margin of uncertainty because of reduced spells, delayed onset of monsoons (from June to October) and heavy rainfall in short spans which was bound to have a significant impact, especially on agriculture. Referring specifically to Kutch, the Director mentioned:

In this area, the uncertainty will never decrease. It is an arid area, the south-west monsoon is not uniform, it comes in spells and pulse, sometimes we can have good rains and some time for twenty days, there will be no rains. In arid areas like Kutch, you will get very few spells, so you need to develop water storage capacity.

(Interview January 2018, Ahmedabad)

For the scientist, in a government research institute who referred to being in a "privileged" position because of her existing networks with other scientists and policymakers, on the one hand, and vulnerable communities (through projects), on the other hand, uncertainty is not merely present in the models but embodied in the ways people perceive, respond and deal with climatic events. She argued that:

Uncertainty does not exist merely at research levels but also in people's perception of the phenomenon i.e. how does it impact them. They [people] understand that things are changing and they would be able to relate with things like rainfall (rainy days have reduced) and temperature (the winters are not that cold). Uncertainty lies in the fact that we do not know how much is changing, whether this is real climate change or can be attributed to a local weather phenomenon.

(Interview September 2016, Gandhinagar) 
As discussed in Chapter 2, global projections on climate change are not particularly helpful when it comes to state or district-level planning. Policymakers usually rely on scientific expertise to understand climate change as a phenomenon, which is often limited to questions of changes in patterns such as the arrival of the monsoons, the severity of floods and the intensity of heatwaves, but this scientific input does not extend to policy planning or strategy development. Most of the scientists interviewed agreed that they faced challenges in communicating with policymakers, where they are often perceived more as "information providers" than substantive "policy shapers" because scientists find it hard to accurately predict local-level impacts given the uncertainties in the scenarios. Policymakers often downplay their advice since they only see the value in "hard" predictions.

In the past two decades, climate change has attracted significant policy attention in the state of Gujarat. In 2009, Gujarat became the first state in the country to establish the Climate Change Department (CCD). Announcing the initiative in the state assembly, Narendra Modi (then Chief Minister of Gujarat) said - "Gujarat government's separate department for climate change will act as a bridge between government and society to address the issues related to global warming" (cited in Business Standard 2013). Though introduced with a lot of fanfare, CCD has predominantly focused on mitigation rather than adaptation while devising the climate strategies of the state. Tasked with the role of mainstreaming climate change action into the state-wide policy of Gujarat, CCD's attempts to this day have been partial and this has been recognised by various policymakers (Roundtable dated January 2018, Gandhinagar). We conducted interviews with bureaucrats in this department who were not very aware of climate change issues but instead focused on the achievements of Gujarat in building the controversial Sardar Sarovar Dam, which was often packaged as a form of climate adaptation (Interview, May 2019, Gandhinagar). Although other departments have a diverse portfolio of projects on energy, agriculture, livestock and rural development that address the impacts of climate change, this often takes place through the route of poverty alleviation rather than deliberately targeting or framing these programmes around the language of climate adaptation.

While climate change is a definitive entry point of discussion with the policymakers, the use of uncertainty was at times met with scepticism. Largely, policymakers were uncomfortable with the use of the term and preferred to talk about climate change than about the "realms that cannot be known". This is explained by a former civil servant in Gujarat in the following way:

The term uncertainty can create policy paralysis. Policymakers usually like to be certain about the course of action and they can work with likely scenarios but not with something that is highly uncertain. We need to justify our decisions [...] uncertainty creates policy chaos, and decisions cannot be taken if the range of uncertainty is too high.

(Roundtable January 2018, Gandhinagar) 
Largely, the actors from "above" acknowledged that climate change impacts are most vigorously felt at the local level, especially in terms of the changes in water supply and resources, health, livelihoods, loss of forest and biodiversity. However, many considered the local level to be like a "blackbox" (Roundtable January 2018, Gandhinagar) where uncertainty is not articulated very clearly. They concurred that the everyday practices of people in terms of living and coping with climate change have not been documented or understood sufficiently, especially by the "above". Largely, there was a tendency to discredit these experiences as anecdotal evidence. This was evident at the roundtable organised in Gandhinagar which was very well attended by policymakers and officials from different departments of the state.

Very often, climate scientists and policymakers dismiss the everyday experiences of local people and situate them as "weather" as opposed to "climate", which has a longer-time horizon (see Chapter 2). However, as argued by Hulme (2017), there are overlaps between the two and it is the instantaneous experience of atmospheric conditions such as wind, temperature, cloudiness, pressure and so on, which averaged over a period of time becomes climate. There are also tensions about the visibility and invisibility of climate change where scientists contend that local people cannot "observe" climate change. However, local people "feel" the manifestations of climate change through changes in resource quantity and quality as well as in terms of impacts on their livelihoods (RudiakGould 2013). Thus, a focus on the everyday practices shows how humans relate to nature encompassing socio-economic and demographic changes, conditions of political economy that impact patterns of resource use, social norms and cultural codes as well as the global flows of capital and labour (Leichenko and O'Brien 2008). We now turn to these experiences and their intersections in the next section.

\section{Uncertainty from "below"}

There is a great deal of regional variation across the sites and the experience of climate-related uncertainties is also differentiated by caste, class and gender. As with most drylands, rainfall is highly erratic and variable across Kutch. Farmers told us that over and above climatic variability, limited access to credit, lack of extension officers, the paucity of information and crop insurance, depletion of groundwater and salinity intrusion are the causes of their current vulnerability (GUIDE 2014).

For resource-dependent communities, who live close to nature, climate change is not a term they use. Rather, they speak of changes in the atmosphere, locally called the havamaan. Similar to the perceptions among the "above", temperature, erratic patterns of rainfall and drought, cyclones and sea-level rise also featured as key climate plots for the local people in Kutch although these were captured through the lens of changes in everyday routines and livelihoods (discussed below). For example, our photovoice initiative in Jimlivand revealed the gendered 
experiences of climate change among the maldhari women. It captured the more embodied, socially and culturally embedded experiences of uncertainty revealed through the powerful images of the "invisible" care economy that sustains the pastoral system on a day-to-day basis (Mehta and Srivastava 2020). Some examples include frequent trips to drying wells in the summer, picking fodder leaves, milking buffaloes and washing the calves, and the role of faith and religion in coping with climatic uncertainties (Mehta and Srivastava 2020). Across the sites, women and young girls reported spending more time in fetching water. For example, in Jalva, where wells are turning saline rapidly, young girls are dropping out of school to help with household chores.

Generally, when asked about the changes in the havamaan, oppressive heat and changes in seasonal calendars were a standard response to "feeling" the changes in the climate. These emerged as central themes during our discussions in both Merka and Jalva. Several interviews highlighted experiences of increased variability over long-term climate change. An ayurvedic doctor, who has lived in Jalva for most of his life, ruminated over the changes in this way:

We have seen some changes after the earthquake [in 2001] but they have become more intense in the last 5-6 years, it is more variable. It is colder but for fewer days while the summers are getting hotter, and the heat lasts for more days. Seasons have also changed. Earlier rains would come at the end of June but now they come in September. Due to the changes in rainfall, crops are also changing.

(Interview February 2016, Jalva)

Several studies have documented how communities that are highly exposed to climate variability adapt to uncertainty by drawing on local cosmologies and indigenous knowledge (IK) systems to predict, forecast and prepare for both immediate and distant futures (Scoones 2004; Mehta 2005; Naess 2013; Hastrup 2013). In the next section, we explore how local people in Merka and Jalva anticipate some of these changes and analyse the social and solidarity networks that they rely on. We also reveal how practices of anticipation are often not enough in conditions of radical uncertainty when ecological uncertainties intersect with wider changes.

\section{Local cosmologies and uncertainty}

Rama Bappa, a Rjput landowner in Merka, and his family own large tracts of land in Merka. He enjoys a lot of respect across different social groups, much to the envy of the Darbars. Farmers often approach him seeking advice for sowing and crop diseases. As we bite into rotla (local bread) smeared with butter, he narrates how farming has changed in the past few decades, with a higher incidence of pest infestation and that seasons have become much harder to predict. Similarly, other farmers also mentioned that their predictions based on lunar calculations 
were increasingly failing them and that nature was becoming hard to predict and prepare for. ${ }^{3}$

In Kutch, local people have historically drawn on IK to plan their livelihoods. They have used traditional methods to predict the arrival of the monsoons and the success and failure of crops. These range from observing seawater currents, animal and bird behaviour, the flowering of particular plants as well as planetary positions in the sky, with many preferring these "signs of nature" to scientific forecasts about rainfall (Mehta et al. 2019). The Rabaris look at the stars and perform certain rituals to make predictions about rainfall. Similarly, fishers in Jalva also rely on the movement of stars, the direction of the wind and the colour of the sea to make weather predictions.

In both Merka and Jalva, village elders are revered as repositories of knowledge. They read changes in the good and bad omens of nature. Binetkar kaka is a 70-year-old Jat, who many Vaghers in Jalva refer to as the "grandfather of fishing". In our conversations along the Jakhau coast, he talked about predictions, the colour of the sea and certain leaves which are only spotted before the onset of monsoons. He was confident that 2016 would be a year of good rainfall, but it did not turn out to be so. ${ }^{4}$

A 2014 GUIDE study reports that scientists found predictions based on IK to be 90-95\% accurate in the 1995-2004 period, but after 2004, they acknowledge that local-level predictions of monsoon patterns have become more uncertain and difficult to predict for local people. A similar observation is made by a scientist, at a research institute in Kutch, who argued that "local people's forecasts are also based on observations but because long term climate and weather patterns are changing, these local forecasts are not working very well" (Interview June 2016; Kutch). In this way, traditions and practices of anticipation are faltering in the face of increased climate variability. Also, as we indicate below, the radical nature of these uncertainties becomes more apparent as they intersect with local livelihoods and resource insecurities.

Everyday practices and experiences around uncertainty are rarely conceptualised around climate change. Instead, they are usually felt and experienced in terms of access to livelihood opportunities which many local people referred to as anishchit (uncertain). In the following sections, we explore what anishchit means for the three predominant livelihoods in Kutch.

\section{Livelihoods on the margins}

Kutch receives the majority of its rainfall through the south-west monsoons between June and September. Although previously (between 1958 and 2001) July was the month of peak rainfall, in recent years that has shifted to September, with maximum rainfall now falling in this month (GUIDE 2014). The problem of salinity ingress is compounded by the indiscriminate invasion of Prosopis juliflora, locally referred to as ganda bawal (mad shrub), an invasive weed originally planted in Kutch to check desertification, but that eventually resulted in the loss 
of arable land. Extreme weather conditions in the form of droughts and floods have often wiped out crops, leaving farmers impoverished and helpless (GUIDE 2014). Since rainfall patterns have become more erratic, farmers find it difficult to plan their seasonal calendars. Rao bhai, a male Rjput farmer, explains how changing seasonal cycles have created challenges in agriculture:

We are used to hot summers, but the temperature seems to be more extreme. Summers are oppressively hot, and winters are longer. Extreme heat and prolonged winters are not good for the crops. Winter rain is not unusual, but it seems to be increasing and is also not good for the crops.

(Interview June 2016, Merka)

In Jalva, the compounded problem of prosopis juliflora along with increased salinity is pushing the farmers outside of agriculture. Several farming families that we spoke to had either abandoned farming or would only take crops after the monsoons. These families are also increasingly migrating to other livelihoods such as offering labour on the lands of other farmers or moving to other smallscale business. For example, Suli-ben, ${ }^{5}$ a female farmer in Jalva who practices dryland farming lamented:

I have spent a lot of money in digging wells and searching for sweet water but no luck so far. I do not think I can continue like this.

(Interview June 2016, Jalva)

Poor agricultural yield has had cascading effects on other livelihoods, especially for the maldharis who graze their livestock in the farms and buy groundnut and wheat chaff as fodder from the farmers. With poor rains and lack of water and fodder/grass in the simara, the maldharis migrate to other parts of Kutch or Gujarat in search of food and water.

Although seasonal migration with animals in lean periods is a way of life for pastoralists, it is becoming increasingly difficult due to shrinking commons, lack of fallow fields to graze on due to perennial irrigation facilities, changing state policies and growing resentment towards pastoralists (Mehta 2005; Mehta and Srivastava 2019). Climate change leading to increased temperature, higher incidence of livestock diseases and shortage of water in summer has also influenced the milk yield of animals (GUIDE 2014). This has resulted in a dramatic increase of buffaloes in the livestock composition because they are better suited to the hot climate. An increase in the number of milk dairies and transportation facilities has also favoured this change (GEC 2011).

For example, the Jats of Jimlivand who once bred and reared camels have also moved onto a more sedentary lifestyle. Until a few decades ago, camels were used for farming, patrolling and transport. However, with changes in agricultural patterns and reduced access to grazing fields, the value of camels has declined and they are no longer an asset. Though buffaloes are more expensive than other 
livestock (cows, sheep or goats), their resistance to heat and higher tolerance to prosopis juliflora are cited as some of the reasons for this preference. They also have the advantages of better feed conversion efficiency, can sustain on poor feed and forage quality and provide higher returns from milk (buffalo milk across breeds has more than $8 \%$ fat) with a better nutritive value of milk (Balhara et al. 2017).

The Jats of Jimlivand comprise the big pastoralists who shift between fishing and livestock rearing. Small maldharis can only afford to keep a limited number of buffaloes and are largely reliant on small ruminants (i.e. sheep and goats) and hence face the brunt of ecological uncertainties. Since goats and sheep are more susceptible to livestock diseases, these maldharis are increasingly finding it difficult to continue with their traditional livelihood. Herders with small ruminants often fall outside of the drought mitigation schemes which largely target large livestock owners and farmers. For instance, Musa bhai, a small maldhari recounts:

If we have good rainfall, then there is no problem but if the rainfall is not good, we are in loss, not profit. We are spending our money on purchasing drinking water, fodder grass, cotton and groundnut leaves and wheat. Livestock diseases have also increased. Now maldharis are migrating with animals in search of fodder and water. This year, there was no water in the sim, we gave the pipeline water to animals. In summer, we need to purchase more tankers. One tanker is 700 rupees. I do not think I can continue like this [...] I do not want my grandson to struggle in the same way.

(Interview February 2016, Jalva)

Similar to other livelihoods, it is estimated that climate changes will have profound effects on the marine ecosystem as warmer sea temperatures will lead to shifts in availability and adaptability of particular species (Harley et al. 2006). Fishing is both a major livelihood and a burgeoning business opportunity on the Kutchi coastline. It was the introduction of mechanised boats from 1981 onwards that led to the gradual development of Jalva as one of the major fishing harbours in the state (Gujarat Ecology Commission 2011).

Most fishers whom we interviewed said that they are now witnessing warmer sea temperatures and a decline in fish catch. Faiz bhai, the head of Jalva's fisher's association, narrates the changes in the following way:

Due to warmer temperatures, there is a decrease in fish production. In the 1990s, the day temperature used to range from 7 to 10 degrees and the night temperature was around 2 degrees. But from 1995 onwards, heat has increased. The fish needs salt as well as freshwater. Industries and salt pan activities have also affected fish production. If the rains are late, the fish breeding period also changes accordingly. Jellyfish is food for the fish, but trawlers are catching this fish because of the high demand in China. The food shortage for fish may also be one of the reasons for the decline in fish production. 
Though several fishers spoke of oppressive heat and hot water, they rarely attributed these to climate change and blamed industrial activities for the problems instead. They were united in their anger towards large fishing trawlers who "break the rules" and go for the catch which is "rightfully theirs" (Interviews, February and June 2016, Jalva). They were also critical of the salt pans and industries, which discharged untreated toxic water into the sea, often killing the fish and destroying the mangroves, which are natural nurseries for fish breeding. Similar complaints were heard from the adjacent Mundra taluka regarding the harmful effects of industrial pollution on the marine and coastal ecosystem.

Across fishing communities in Mundra and Abdasa, fishers have noticed several changes in their habitats and attribute this loss to port activities, mangrove denudation and waste that is dumped into the sea (Srivastava and Mehta 2017). While the destruction of mangroves has resulted in the decline in fish catch, fishers' access to water channels is also blocked as the coastline is now populated by industries. Feroz bhai, ${ }^{6}$ a veteran fisher, explained:

Fishing is our livelihood. My father, my grandfather, all were fishers. We have been involved with fishing [for a long time]. For the past six to seven years it has been particularly bad [...] they [industries] draw water from the sea to cool their plants, small fish get stuck in the process and die. Then they release hot water. Fish go away[...] A lot of big projects come up on the coast $[. .$.$] All these factors lead to less catch.$

(Interview August 2016, Mundra).

While the Vaghers and non-native fishers still manage to get some catch, it is the Kolis who have faced the brunt of these changes. The loss of mangrove cover and industrial pollution has also affected creek fishing. Referring to the fish trawlers, one Koli fisher lamented that "the big fish are eating the small fish [i.e. Kolis], and we have nowhere to go" (Group discussion February 2016, Jalva).

Thus, the experiences of uncertainty from "below" are mediated by relations of power within the "community" and asserted by more powerful actors such as the industries and the state. The livelihoods perspective underlines how climate change intersects with other political, social and economic factors for these marginalised communities as they continue to live with highly unfair and unequal conditions that have been imposed on them through social, historical and political arrangements.

The "above" takes an aggregate view of uncertainty, albeit realising the value of local experiences and the need for a more targeted approach, mostly in the form of technical interventions. The perceptions of the "below", by contrast, broaden the understanding of climate from an experience of an atmospheric phenomenon to lived realities as climate change intersects with various transitions in Kutch. These interactions are also facilitated by an alliance of actors within and outside of the state, bringing in the new constellations that emerged after the 2001 earthquake. We now turn to the role of some of these networks in the next section that this volume characterises as the "middle". 


\section{The "middle": intermediaries for transformation}

After the 2001 earthquake, NGOs working on reconstruction and rehabilitation $(\mathrm{R}$ and $\mathrm{R}$ ) rapidly developed expertise in disaster reconstruction while simultaneously addressing wider issues concerning Kutch's development trajectory. This became all the more crucial as corporates entered into Kutch in a big way after 2001. One NGO worker describes the changed context as follows: "We were so busy working on $\mathrm{R}$ and $\mathrm{R}$ that we hadn't realised that a corporate takeover had taken place" (Interview, October 2016, Bhuj).

We have already described the impacts of aggressive industrialisation on Kutch's coast and landscapes. Many NGOs have resisted these processes together with local communities. However, in some cases, new alliances between India's big corporate houses (Adanis, Ambanis, Tatas and others) and the NGOs have also emerged over the past two decades via the route of corporate social responsibility (CSR). Shrinking development funds from the state often leave CSR money as the only or predominant source of funding for many development NGOs and research organisations in Kutch (Srivastava and Mehta 2017). While some of the NGOs argue that this provides an opportunity "to bring about change from within by having a seat at the table", they also acknowledge that these relations are ridden with tensions (Interview October 2016, Bhuj).

Industries have also roped in scientists to support their compensatory afforestation and environmental assessment activities (Srivastava and Mehta 2017). Having worked in these areas for decades, these scientists not only bring along technical expertise but are also able to act as interlocutors between the industry and the local communities. Against the backdrop of shrinking development funding, these corporate-scientist and corporate-NGO alliances may have provided some legitimacy to the "development" discourse in Kutch as they are co-opted in the neoliberal project of development in Kutch (Srivastava and Mehta 2017). By contrast, more activist-oriented groups have challenged these top-down systems of intervention.

Thus, the "middle" is geographically varied, holds diverse positions and engages both with the community and the "above". As the "middle" often works within alliances, they often seamlessly merge into the "above" and "below" depending on the context and issue at hand. This also accounts for their heterogeneity and different strategies which include contestation, subversion and collaboration. For example, in the case of CSR, some scientists and NGOs tend to assume the role of the "above" dictating policies and programmes, while in other instances, they also identify themselves as the "middle" that brokers information from one group to the other.

Thus, torn between the "above" and "below", and recognising the deep divide, some NGOs compare their position to that of a trishanku (a state of limbo with conflicting aims and ambitions) (Interview June 2016, Rapar). For instance, a Gandhian social worker who has been working for tribal welfare in Rapar taluka states: 
Yes, there is uncertainty, but the uncertainty of the community is very different from the uncertainty of the "above". Their vocabularies are very different, and they speak in a different language. The "above" wants plans and strategies and the "below" is concerned about day-to-day food and work. Local communities often worry whether they will have food on the table for the next meal and if their kids would get education or jobs. And the "middle" is diverse and not united.

(Interview June 2016, Rapar)

However, several NGOs are also working with communities to provide greater support to address these uncertainties. For example, an organisation working on groundwater issues in Kutch admits that the landscape of Kutch may have changed, but bridging this divide is crucial to navigating through this complex environment (Interview October 2016, Bhuj). They now train local people as bhujal jankars (those who have knowledge about groundwater) to understand groundwater ecology and to work on groundwater conservation in their communities. Several such bottom-up and transformative initiatives are currently underway in Kutch. One such case concerns the revival of camel rearing in Kutch, to which we now turn.

\section{Restoring pastoral livelihoods}

As discussed above, pastoral communities have been severely affected by industrial development on the Kutchi coastline. While local people bemoan the loss of their coastline to ports and industrial enclaves, it is the pastoralists who have lost access to grazing lands that are either destroyed, encroached upon or made off-bounds for them. A Kachchh Camel Pastoralists' Organisation study notes that camel grazing lands are shrinking due to widespread encroachment and degradation due to largescale industrialisation in the coastal areas (KUUMS 2010). The report alleges that steel and thermal power plants have appropriated huge areas of mangroves, making them hard to access or useless for grazing. Being a border district, the threat of terrorism and international security is also often overplayed to deny common people access to the coast as well as coastal resources (Srivastava and Mehta 2017).

In Phuleri vand, the camel headcount has dipped from 10,000 to 80 camels over the past few decades. "We just can't get enough fodder, after a port and two thermal power plants took away much of the mangroves, and forest guards prevent entry to some other areas", laments Jarod-bhai. He states:

With the company's arrival, people started selling their camels and some have migrated to other places in search of fodder. We are assuming that if this grazing land problem is not solved, in future no single camel will be available in this vand. We have to fight the company and the forest department. 
The massive degradation of mangroves is also threatening the survival of an indigenous breed of camels, the celebrated kharai (salty) camels that can browse on land and also swim across to the bets (mangrove islands). Mangroves constitute about $70 \%$ of the kharai's diet (Shrivastava 2013). In the monsoon, they swim to the bets and stay there for a few months getting the crucial nutrition required to make milk. However, their access to these mangroves is now very compromised, as explained by an ecologist at the NGO Sahjeevan:

Mangroves [islands] are still there as per their [camel's] knowledge but they cannot access those mangrove islands due to all the industrial activities. So now they keep on migrating from one place to another. The herders are selling their animals. Earlier they had 500 to 600 camels in this particular area. Now they hardly have about 100 camels.

(Interview September 2016, Bhuj)

Breeding of the kharai camel is the main source of livelihoods for many Jat and Rabari communities in several villages of Abdasa, Mundra, Lakhpat and Bhachau talukas. However, mainstream conservation debates within the state often blame herding and grazing practices for the denudation of mangroves (Srivastava and Mehta 2017). Scientists argue that overgrazing, "unscientific grazing patterns", that is, camels browsing on leaves and damaging the tree and cutting of leaves are responsible for the destruction of mangroves. By contrast, herders vehemently oppose this discourse and talk of the synergistic relationship between the camel and the mangroves. The Jats denounce the claim that camels could "ever be bad for mangroves because they share a natural relationship with the cheria (mangroves)" (BCP 2012; Srivastava and Mehta 2017). The kharai camels play an integral role in the pastoral landscape, and both men and women describe a deep connection with these camels. However, with aggressive industrialisation, their pastoral identity and landscape are now at risk. As a consequence, several Jat and Rabari herders have migrated to low-scale contractual jobs in the companies or left for towns and urban centres to work as security guards or taxi drivers (Mehta and Srivastava 2019).

Over the past few years, however, alliances have been made between civil society and local herders to preserve the pastoral identity and restore the landscape. The kharai camels have now been recognised in India as a distinct breed or "threatened" species that need protection. Sahjeevan is working closely with these marginal communities to revive their indigenous systems and restore the native habitats, food stocks and grazing routes of the kharai. The intervention is transformative in that it hopes to counter received wisdom regarding pastoralism on many fronts (particularly so on grounds of being unsustainable), while also using innovative methods and alliances to counterarguments and pressures that threaten to disrupt pastoralist practices (Interview October 2016, Bhuj). 


\section{Compounded uncertainties under COVID-19}

The first case of COVID-19 in Kutch was recorded in Lakhpat taluka, not far from where we are doing research. ${ }^{7}$ Around 30 families with about 500 kharai camels use the tropical thorn forests and mangroves in these areas to graze their animals (Mehta et al. 2020). Several herders whom we spoke to over the phone narrated the problem of fodder and access to pastures in the early period of the lockdown. The lockdown coincided with the crucial summer months where sources of fodder and water have always been challenging. The immediate effect of the lockdown was felt acutely in terms of mobility restrictions, lack of food supplies and suspension of dairy activities. Since the villages are located in the remote border areas, access to hospitals, banks and shops was highly restricted. A Jat herder remarked: "food is a big problem, everything is closed and the shops and markets are also quite far" (Telephone interview August 2020). The easing of lockdown in May did not resolve the problem of mobility restrictions and suspension of livelihood activities. This meant that there was no liquid cash for purchasing essential commodities especially food items. In the months that followed, Kutch also experienced higher than average rainfall leading to flooded farms and waterlogging in various parts of the Abdasa taluka. This excess rainfall may have helped pastoralists but those who farm have been disproportionately hit by the devastation having lost their crops and agricultural income. These intersections of extreme climate variability and the health crises reveal the structural inequalities that have compounded the challenges faced by these marginal communities and cascaded into different livelihoods.

\section{Discussion and conclusion}

This chapter has argued that radical uncertainty, originating from the combination of changes in biophysical stressors, on the one hand, and socio-political changes such as marketisation and neoliberal trends, on the other hand, have exacerbated the vulnerabilities of the "below". Traditional methods of adapting to scarcity and droughts (e.g. temporary migration, change in cropping patterns, subsistence fishing) are struggling to deal with these radical uncertainties. Although traditional livelihoods around pastoralism, fishing and dryland agriculture are configured around ecological uncertainties, these have witnessed an almost tectonic shift in the wake of rapid industrialisation that has taken place in Kutch in the past two decades. These livelihoods are also interdependent, as uncertainty experienced in one sector cascade into the other (e.g. maldharis having to buy fodder when agriculture fails).

The "above" takes an aggregate view of uncertainty, albeit realising the value of local experiences and the need for a more targeted approach mostly in the form of technical interventions that seldom reflect the ecological and social diversity of this district. Furthermore, institutional silos and the mitigation/ energy focused bias in the climate strategy of Gujarat have meant that climate policy remains blind to the dryland dynamics of this ecologically diverse district 
(see Mehta 2005). This has hindered the mainstreaming of substantive pro-poor adaptation policies, which could include strengthening dryland agriculture and pastoralism rather than neglecting or denigrating them. This has often resulted in, for example, pastoralists giving up their livelihood in favour of casual labour.

Climate scientists, working within the remits of their discipline, certainly recognise the challenges of uncertainty and its associated limitations in modelling. Although integrating people's perceptions into climate science and modelling may be difficult, they are keen to "learn" how people cope with uncertainty and want to work towards providing information in real time to support livelihoods planning and diversification.

The perceptions of the "below", by contrast, broaden the understanding of climate from an experience of the atmospheric phenomenon to lived realities as climate variability intersects with various transitions in Kutch. Thus, the experiences of uncertainty from "below" are mediated by relations of power within the "community" and asserted by more powerful actors such as the industries and the state.

The "middle" comprises an assemblage of actors who have differing views and positions with regard to climate change and uncertainties. Most of the NGOs agree that industrialisation has aggravated the uncertainties faced by these marginalised communities, but they often find themselves tied to the political economy of aid and grants that limit the possibilities of working for transformative change. Through state- and corporate-funded projects, the "middle" acts as an intermediary when the communities are tied into relationships of patronage and dependency with either the state (through scientists) or the industries (through CSR projects) although these relationships are ridden with contradictions and internal tensions

In conclusion, this chapter has highlighted the various manifestations and perceptions of uncertainty amongst the "above", "middle" and "below" in Kutch. We have shown that changes in the wider political economy are depleting the adaptive capacity of people and, in most cases, accentuating their vulnerability. The experience of this radical uncertainty is often mediated by power relations between the "above", "middle" and "below" which shapes their interactions and responses to uncertainty. Alliances forged between different actors - state and corporate, CSOs and corporations and scientists and communities - have intensified the capitalist growth trajectories producing winners and losers. In parallel, new alliances are emerging which seek to challenge these incumbent neoliberal regimes. These initiatives demonstrate the beginnings of the unruly political re-alignments that are seeking to challenge incumbent power structures as well as top-down systems of knowledge and could potentially foster pathways to social transformation.

\section{Acknowledgement}

The authors would like to thank Fazilda Nabeel, Maxmillan Martin, Jagruti Sanghvi, Subir Dey and Rohit Jha for their research assistance. 


\section{Notes}

1 These are areas demarcated in India to promote investment and trade. Business and tax laws are far more relaxed in the SEZs than in the rest of the country.

2 To respect anonymity, names of respondents have been changed and we have provided pseudonyms for the hamlets in Kutch.

3 Field Journal of Srivastava, 2016.

4 Field Journal of Srivastava, 2016.

5 Means sister; in Gujarati, women are often addressed as ben as a mark of respect.

6 Means brother; in Gujarati, men are often addressed as bhai as a mark of respect.

7 This section draws on our work in two ongoing projects: TAPESTRY https:// steps-centre.org/project/tapestry/; ANTICIPATE: https://www.ids.ac.uk/projects/ anticipating-futures-forecasting-and-climate-preparedness-for-co-located-hazardsin-india-anticipate/.

\section{References}

Asher, M. 2008. 'How Mundra Became India’s Rotterdam'. Available at: http://bit. ly/2wUu2xC (accessed on 24 August 2016).

Balhara, A., V. Nayan, A. Dey, K.P. Singh, S.S. Dahiya and I. Singh. 2017. 'Climate Change and Buffalo Farming in Major Milk Producing States of India - Present Status and Need for Addressing Concerns'. The Indian Journal of Animal Sciences, 87(4): 403-411.

Barney, K. 2009. 'Laos and the Making of a 'Relational' Resource Frontier'. The Geographical Journal, 175(2): 146-159. https://doi.org/10.1111/j.1475-4959.2009.00323.x

Bharwada, C. and V. Mahajan. 2007. Mangroves and Maldharis of Kutch: Understanding Coastal Pastoralists' Dependence on Mangroves. Vadodara: Gujarat Ecology Commission.

Business Standard. 2013. 'Gujarat to Set up Asia's First Dept for Climate Change'. Business Standard, Mumbai, 19 January.

Eriksen, S.H., A.J. Nightingale and H. Eakin. 2015. 'Reframing Adaptation: The Political Nature of Climate Change Adaptation'. Global Environmental Change, 35: 523-533. https://doi.org/10.1016/j.gloenvcha.2015.09.014

Gajjar, S.P., C. Singh and T. Deshpande. 2018. 'Tracing Back to Move Ahead: A Review of Development Pathways that Constrain Adaptation Futures'. Climate and Development, 11(29): 1-15. https://doi.org/10.1080/17565529.2018.1442793

Government of Gujarat. 2020. 'Kachchh District Profile'. Available at: https://kachchh. nic.in/district-at-a-glance/ (accessed on 10 November 2020).

Government of India. 2011. 'Kachchh (Kutch) District: Census 2011 Data'. Available at: https://www.census2011.co.in/census/district/182-kachchh.html (accessed on 17 May 2018).

GUIDE. 2014. Climate Change and Its Uncertainty: Dryland Scenario. Bhuj: GUIDE.

Gujarat Ecology Commission. 2011. Trends of Changing Climate and Effects of Eco-Environment of Kachchh District, Gujarat. Vadodara: Gujarat Ecology Commission.

Haraway, D. 1988. 'Situated Knowledges: The Science Question in Feminism and the Privilege of Partial Perspective'. Feminist Studies, 14(3): 575-599. https://doi. org $/ 10.2307 / 3178066$

Harley, C.D.G., A. Randall Hughes, K.M. Hultgren, B.G. Miner, C.J.B. Sorte, C.S. Thornber, L.F. Rodriguez, L. Tomanek and S.L. Williams. 2006. 'The Impacts of Climate Change in Coastal Marine Systems'. Ecology Letters, 9(2): 228-241. doi:10.1111/j.1461-0248.2005.00871.x 
Hastrup, K. 2013. 'Anthropological Contributions to the Study of Climate: Past, Present, Future'. Wiley Interdisciplinary Reviews: Climate Change, 4(4): 269-281. https://doi. org/10.1002/wcc. 219

Hulme, M. 2017. Weathered: Cultures of Climate. London: SAGE Publications.

Ibrahim, F. 2007. 'Capitalism, Multiculturalism and Tolerance: A Perspective on 'Vibrant Gujarat". Economic and Political Weekly 42(34): 3446-3449.

Ibrahim, F. 2009. Settlers, Saints and Sovereigns: An Ethnography of State Formation in Western India. New Delhi: Routledge.

Kachchh Camel Breeders Association. 2013. Biocultural Community Protocol of the Camel Pastoralists of Kachchh. Bhuj: Kachchh Camel Breeders Association.

Kay, J. and M. King. 2020. Radical Uncertainty: Decision-Making for an Unknowable Future. London: The Bridge Street Press.

Kohli, K. and M. Menon. 2016. 'The Tactics of Persuasion: Environmental Negotiations Over a Corporate Coal Project in Coastal India'. Energy Policy, 99: 270-276. https:// doi.org/10.1016/j.enpol.2016.05.027

Lehmann, J., F. Mempel and D. Coumou. 2018. 'Increased Occurrence of Record-Wet and Record-Dry Months Reflect Changes in Mean Rainfall'. Geophysical Research Letters, 45(24): 13468-13476. https://doi.org/10.1029/2018GL079439

Leichenko, R. and K. O'Brien. 2008. Environmental Change and Globalization: Double Exposures. Oxford: Oxford University Press.

Mahapatra, M., R. Ramakrishnan and A. Rajawat. 2015. 'Coastal Vulnerability Assessment of Gujarat Coast to Sea Level Rise Using GIS Techniques: A Preliminary Study'. Journal of Coastal Conservation, 19: 241-256.

Mehta, L. 2000. 'Drought Diagnosis: Dryland Blindness of Planners'. Economic and Political Weekly, 35(27): 2439-2445.

Mehta, L. 2005. The Politics and Poetics of Water: Naturalising Scarcity in Western India. New Delhi: Orient Longman.

Mehta, L., P. Joshi, and M.R. Bhatt. 2020. 'How Pastoralists in Kutch Respond to Social and Environmental Uncertainty'. Available at: https://steps-centre.org/blog/ how-do-pastoralists-in-kutch-respond-to-social-and-environmental-uncertainty/ (accessed on 8 January 21)

Mehta, L. and S. Srivastava. 2019. 'Pastoralists without Pasture: Water Scarcity, Marketisation and Resource Enclosures in Kutch, India'. Nomadic Peoples, 23(2): 195217. https://doi.org/10.3197/np.2019.230203

Mehta, L. and S. Srivastava. (2020). 'Uncertainty in Modelling Change: The Possibilities of Co-production through Knowledge Pluralism', in Scoones, I. and Stirling, A. (eds.), The Politics of Uncertainty: Challenges of Transformation. Routledge, pp. 99-11.

Mehta, L., S. Srivastava, H.N. Adam, S. Bose, U. Ghosh and V.V. Kumar. 2019. 'Climate Change and Uncertainty from 'Above' and 'Below': Perspectives from India'. Regional Environmental Change, 19: 1533-1547. https://doi.org/10.1007/s10113-019-01479-7

Naess, L.O. 2013. 'The Role of Local Knowledge in Adaptation to Climate Change'. Wiley Interdisciplinary Reviews: Climate Change, 4(2): 99-106. https://doi.org/10.1002/ wcc. 204

Pandey, V., A. Shekh and R. Parmar. 1999. 'Occurrence of Droughts and Floods over Gujarat'. Journal of Agrometeorology, 1(2): 177-181.

Pandey, V., H. Patel and B. Karande. 2009. 'Impact Analysis of Climate Change on Different Crops in Gujarat, India'. Paper presented at the Impact of Climate Change on Agriculture Workshop, Anand Agricultural University, Ahmedabad, 17-18 December. 
Pelling, M. 2011. Adaptation to Climate Change: From Resilience to Transformation. London: Routledge.

Ribot, J. 2014. 'Cause and Response: Vulnerability and Climate in the Anthropocene'. Journal of Peasant Studies, 41(5): 667-705. https://doi.org/10.1080/03066150.20 14.894911

Rudiak-Gould, P. 2013. “We Have Seen It with Our Own Eyes”: Why We Disagree about Climate Change Visibility'. Weather, Climate, and Society, 5(2): 120-132. https:// doi.org/10.1175/WCAS-D-12-00034.1

Sarkar, J., J. Chicholikar and L. Rathore. 2015. 'Predicting Future Changes in Temperature and Precipitation in Arid Climate of Kutch, Gujarat: Analyses Based on LARS-WG Model'. Current Science, 109(11): 2084.

Sarkar, S. 2020. 'Cyclones Rise as Climate Change Heats up Indian Ocean'. Available at: https://indiaclimatedialogue.net/2020/06/05/cyclones-rise-as-climate-changeheats-up-indian-ocean/ (accessed on 10 November 2020).

Scoones, I. 2004. 'Climate Change and the Challenge of Non-Equilibrium Thinking'. IDS Bulletin, 35: 114-119. https://doi.org/10.19088/1968-2020.116.

Scott, J.C. 1998. Seeing Like a State: How Certain Schemes to Improve the Human Condition Have Failed. New Haven: Yale University Press.

Shrivastava, K. S. 2013. The Sinking Ship'. Available at: http://www.downtoearth.org. in/coverage/the-sinking-ship-40705 (accessed on 24 September 2016).

Solecki, W., M. Pelling and M. Garschagen. 2017. 'Transitions between Risk Management Regimes in Cities'. Ecology and Society, 22(2): 38. https://doi.org/10.5751/ ES-09102-220238

Soneji, V. 2017. 'The Camels and the Sea'. Available at: https://www.th ehindu.com/ news/national/the-camels-and-the sea/article18190869.ece/p hoto/1/ (accessed on 12 August 2017).

Srivastava, S. and L. Mehta. 2017. The Social Life of Mangroves: Resource Complexes and Contestations on the Industrial Coastline of Kutch, India. Brighton: ESRC STEPS Centre.

Samerth Trust. 2013. 'XXX Village Watershed Plan: Internal NGO Report'. Unpublished.

Tschakert, P. 2007. 'Views from the Vulnerable: Understanding Climatic and Other Stressors in the Sahel'. Global Environmental Change, 17: 381-396. https://doi. org/10.1016/j.gloenvcha.2006.11.008

Walker, W., P.E. Harremoës, J. Rotmans, J.P. van der Sluijs, M.B.A. van Asselt, P. Janssen and M.P. Krayer von Kraus. 2003. 'Defining Uncertainty: A Conceptual Basis for Uncertainty Management in Model-Based Decision Support'. Integrated Assessment, (1): 5-17. https://doi.org/10.1076/iaij.4.1.5.16466 